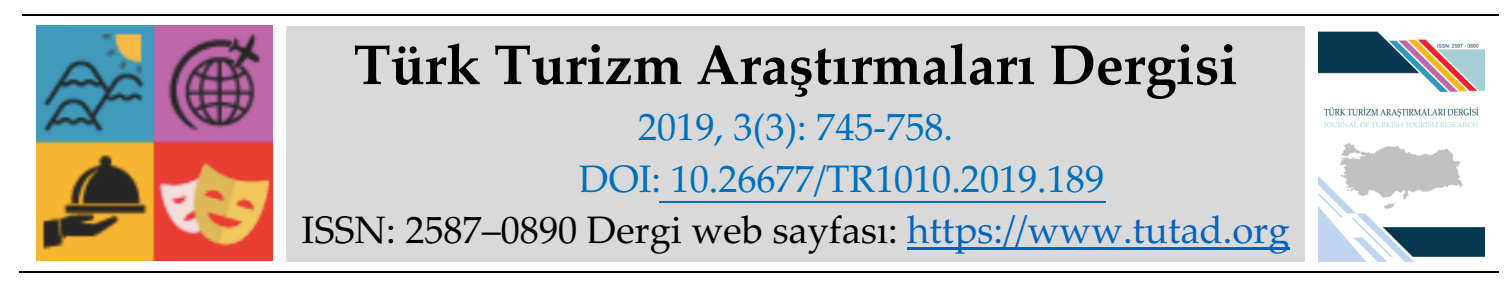

ARASTTIRMA MAKALESI

\title{
Uluslararası Turist Rolü Tipolojisinin Kuşaksal Bağlamda Analizi: Bir Bölümlendirme Önerisi
}

Dr. Öğretim Üyesi Funda BAYRAKDAROĞLU, Muğla Sıtkı Koçman Üniversitesi, İktisadi ve İdari Bilimler Fakültesi, İşletme Bölümü, Muğla, e-posta: fkaya@mu.edu.tr ORCID: https://orcid.org/0000-0003-2340-7463

Doktora Öğrencisi Pınar ELDEM ÇULHAOĞLU, Muğla Sıtkı Koçman Üniversitesi, Sosyal Bilimler Enstitüsü, İşletme Anabilim Dalı, Muğla, e-posta: peldem@gmail.com ORCID: https://orcid.org/0000-0002-2977-7863

Öz

Son yılların önemli bir araştırma alanı olan kuşaklar insan kaynakları, eğitim ve tüketici davranışları gibi çeşitli disiplinler açısından ele alınmakla birlikte, turizm literatürü için oldukça yeni ve yeterince incelenmemiş bir konudur. Buna rağmen, kuşakların farklı ve çeşitlenen özelliklerinden yola çıkılarak turizm pazarında anlamlı bölümlere ulaşmak mümkündür. Çünkü her bir kuşağın kendine özgü değerleri, öncelikleri ve amaçları söz konusudur. Bu çalışma, turizmde bölümlendirme önerisi olarak kuşakların uluslararası turist rollerinin nasıl farklılaştığ 1 üzerine yürütülmüştür. Anket yöntemiyle toplamda 671 katılımcıdan toplanan verilerden elde edilen bulgulara göre, çalışma kapsamında ele alınan Bebek Patlaması Kuşağı Kuşağı ve $Z$ Kuşağı turistlerinin kültür yönelimli boyut, destinasyon yönelimli boyut, seyahat hizmetleri boyutu ve sosyal temas boyutu açısından farklı roller üstlenmekte ve çeşitli beklentiler ile turizm tercihlerinde bulunmaktadırlar. $\mathrm{Bu}$ bulgulara dayanarak, turizm pazarı, bölümlendirme kriteri olarak kuşaklara bağlı olarak ortaya çıkan bu farklılıklara göre bölümlendirilebilir.

Anahtar Kelimeler: Turist Rolü Tipolojisi, Bebek Patlaması, X, Y, Z

Makale Gönderme Tarihi: 04.05.2019

Makale Kabul Tarihi: 07.07.2019

\footnotetext{
Önerilen Atıf:

Bayrakdaroğlu, F. ve Eldem Çulhaoğlu, P. (2019). Uluslararası Turist Rolü Tipolojisinin Kuşaksal Bağlamda Analizi: Bir Bölümlendirme Önerisi, Türk Turizm Araştırmaları Dergisi, 3(3): 745-758.

(C) 2019 Türk Turizm Araştırmaları Dergisi.
} 


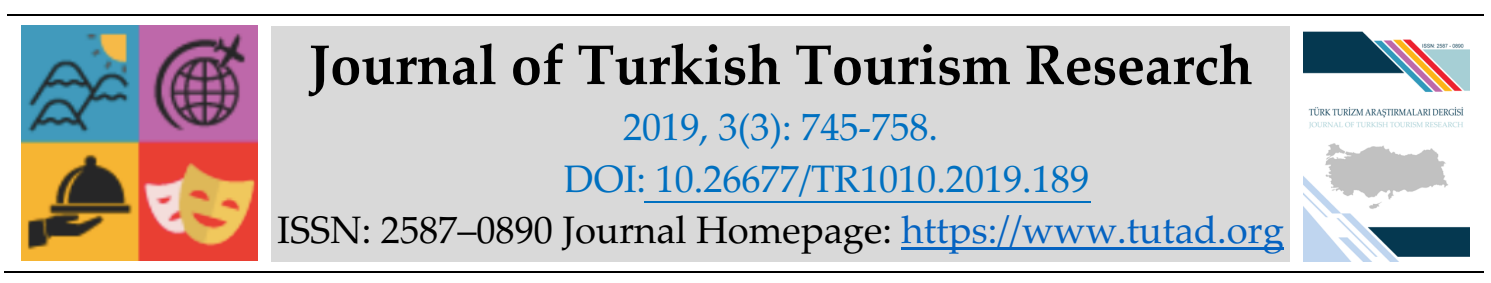

\title{
$\underline{\text { RESEARCH PAPER }}$
}

\section{Analysis of International Tourist Role Typology in the Context of Generations: A Segmentation Proposal}

Asst. Prof. Dr. Funda BAYRAKDAROĞLU, Muğla Sitkı Koçman University, Faculty of Economics and Administrative Sciences, Department of Business Administration, e-mail: fkaya@mu.edu.tr ORCID: https://orcid.org/0000-0003-2340-7463

PhD Candidate Pınar ELDEM ÇULHAOĞLU, Muğla Sıtkı Koçman University, Institute of Social Sciences, Department of Business Administration, e-mail: peldem@gmail.com

ORCID: https://orcid.org/0000-0002-2977-7863

\begin{abstract}
Although the generations, which are an important area of research in recent years, are studied from various disciplines such as human resources, education and consumer behaviors, they are quite new and not examined enough for tourism literature. However, it is possible to reach significant segments in tourism market based on the different and diversified characteristics of generations because each generation has its own values, priorities and objectives. This study has been carried out on how the international tourist roles of generations differentiate as a proposal for segmentation in tourism. According to the findings of data collected with survey method from 671 participants in total, the Baby Boomers, Generation X, Generation Y and Generation Z tourists who are considered within the scope of the study have different roles in terms of culture oriented dimension, destination oriented dimension, travel services dimension and social contact dimension, and make tourism decisions with various expectations. On the basis of these findings, the tourism market can be segmented according to these differences, depending on the generations as a segmentation criterion.
\end{abstract}

Keywords: Tourist Role Typology, Baby Boomer, X, Y, Z

Received: 04.05.2019

Accepted: 07.07.2019

\section{Suggested Citation:}

Bayrakdaroğlu, F. and Eldem Çulhaoğlu, P. (2019). Analysis of International Tourist Role Typology in the Context of Generations: A Segmentation Proposal, Journal of Turkish Tourism Research, 3(3): 745-758.

(C) 2019 Türk Turizm Araştırmaları Dergisi. 


\section{Gíriş}

Turizm sektörü Türkiye ekonomisinin en önemli alanlarının başında gelmektedir. Ülke içerisinde her mevsim ayrı bir turizm türünün yapılabildiği düşünüldüğünde, turizm sektöründeki potansiyel daha derin bir anlam ifade etmektedir. Bununla birlikte, dijitalleşen ve küreselleşen koşullarda diğer sektörlerde olduğu gibi turizmde de rekabet oldukça yoğun bir şekilde hissedilmekte ve rekabetçi olmak için günün gerekleri her geçen gün farklılaşmaktadır. Özellikle turizm sektöründe hizmet ve tüketimin neredeyse aynı anda olduğu bir süreçte dinamik olmak çok önemlidir. Dinamizmi ön plana çıkaracak en önemli unsur ise pazar bölümlendirmenin etkin ve verimli şekilde yapılabilmesidir. Morrison'un da (2010) belirttiği gibi tüm pazarı bölümlere ayırmaktaki temel hedef pazarlama faaliyetlerini belirli alanlarda yoğunlaştırmak ve elbette bütçeyi etkin kullanmaktır.

Her ne kadar turizm pazarı bireylerin sosyo-demografik ve davranışsal özellikleri gibi mikro düzeyde ve ülkelerin sosyo-ekonomik, politik, kültürel ve coğrafi özellikleri gibi makro düzeyde bölümlendirilse de (Lin vd., 2019), yaş temelli bir konu olan ancak yalnızca bununla sınırlı kalmayan kuşak kavramı da anlamlı bir bölümlendirme kriteri olarak düşünülebilir. Bununla birlikte, turizm araştırmalarında kuşaklar konusuna yeterince değinilmediği görülmektedir. Oysa çeşitli perspektiflerden kuşaklar üzerinde yürütülen incelemeler farklı kuşakların kendine özgü turizm tercihleri, tutum ve davranışlarının anlaşılmasında önemli ipuçları sunacaktır (Özel, 2017: 3).

Bununla birlikte, çeşitli yazarlar (Fan vd., 2017; Chen ve Huang, 2018a; Chen ve Huang, 2018b) tarafından incelenen ve farklı şekillerde isimlendirilen turist tipolojileri turizm araştırmalarında sıkça ele alınmış bir konudur. Ancak literatürde turist tipolojileri ile turizmde kuşakların daha önce yeterince ilişkilendirilmediği görülmüş ve bu çalışma ile bu boşluğun doldurulması amaçlanmıştır. Buradan hareketle, bu çalışmada Mo vd. (1993) tarafından öne sürülen uluslararası turist rolü tipolojisi ile Bebek Patlaması Kuşağı, X Kuşağı, Y Kuşağı ve Z Kuşağı turistleri arasındaki ilişki incelenmiştir.

\section{LITERATÜR İNCELEMESİ}

Bir destinasyonu ziyaret eden turistlerin birtakım karakteristikleri üzerinde gruplandırmak, başka bir ifadeyle tipolojiler çıarmak turizm literatürünün önemli konuları arasında yer almaktadır. İlk olarak Cohen'in (1972) yaklaşımıyla başlayan tipolojiler günümüzde çok çeşitli perspektiflerde gruplansa da; çoğunlukla yaş, aile yaşam dönemi gibi demografik temeller ve tatil aktiviteleri, seçilen turizm bölgesi ya da seyahat etme sıklığı gibi davranışsal temellerde ağırlık kazanmaktadır (Kayar, 2008). Hangi temel dikkate alınırsa alınsın, tüm tipolojilerin ortak noktası etkin ve kapsamlı bir turizm politikasının oluşturulmaya çalışılmasıdır (Coccossis ve Constantoglou, 2006). Dolayısıyla, turizm pazarına ilişkin farklı tipolojiler ortaya koymaya olan ihtiyacın sürekli olduğu aşikârdır.

Literatürde belki de en çok üzerinde durulan tipolojilerden biri yenilik-aşinalık ekseninde Cohen (1972) tarafından oluşturulmuş tipolojidir. Yenilik-aşinalık ekseninde turistlerin çeşitli tiplere ayrılmasına ilişkin turist deneyimlerine dayalı olarak dört çeşit sınıflandırma söz konusudur. Bunlar; örgütlenmiş kitle turist, bireysel kitle turist, araştırıcı (kaşif) turist ve başıboş turisttir (Cohen, 1972: 64). Cohen'in tipolojisi turizm literatüründe önemli düzeyde atıf alsa da ampirik olarak test edilmediği yönünde eleştirilmektedir (Jiang vd., 2000).

Farklılaşan turist tipolojilerinin temelini oluşturan iki tipolojiden bir diğeri ise Plog'un (1977) alosentrik ve psikosentrik tipolojisidir. Bu tipolojilerde alosentrik "bedenin rahatlamasına 
yönelik" olmayı, psikosentrik ise bedenden çok ruhun rahatlamasına yönelik bir tipolojiyi ifade etmektedir (Plog, 1977: 56). Ancak Kayar'a (2008) göre, bu tür sosyo-psikolojik tipolojiler kavramsallaştırma açısından değerli katkı sunmakla birlikte, karar verme sürecinde pratik olmaktan uzaktır. Bununla birlikte, bu tipolojilerin tutumsal bileşeni ölçmeye yönelik standartlaştırılmış bir araç olmaktan yoksun olmaları en önemli eleştiriler arasında yer almaktadır (Mo vd., 1993: 321). Bu nedenle, Mo vd., (1993) Cohen'in tipolojisini test ederek geçerli ve güvenilir bir tutumsal ölçek ortaya koymuştur. Uluslararası turist rolü olarak nitelendirilen bu tipolojiye göre, "destinasyon yönelimli boyut", "turist hizmetleri boyutu", ve "sosyal temas boyutuna" göre turistler çeşitli tercihlerde ve davranışlarda bulunmaktadırlar.

Dahası, insan davranışları çok karmaşıktır ve turizm tercihinde bulunurken yalnızca bir kişinin tercihi ile karar verilmemektedir. Aile, akraba ve arkadaşların etkisi ayrıca ekonomik ve sosyal faktörler de çok önemlidir. Tipolojilerin zamanla değişim gösterebileceği göz önüne alınmalıdır. $\mathrm{Bu}$ nedenle, turizm literatüründe nispeten daha az incelenen bir konu olan kuşaklar ile tipolojilerin yeniden yorumlanmasının önemli bilgiler sunması beklenmektedir. Çünkü turizm pazarlamasında turistik ürün ve hizmetlerin doğru şekilde sunulması dişında, turistlerin ilerleyen zamanlarda oluşabilecek gereksinimlerini, beklentilerini ve karar önceliklerini anlayabilmek de gereklidir. Bu nedenle, dinamizmi yüksek olan turizm sektöründe kuşaklar arası farklılıkların incelenmesi turistik ürün yapılarının değiştirilmesi ve pazarlama faaliyetlerinin güncellenmesi açısından bir zorunluluğa dönüşmüştür (Güzel, 2018: 1).

TDK tarafından "yaklaşık olarak aynı yıllarda doğmuş, aynı çağın şartlarını, dolayısıyla birbirine benzer sıkıntıları, kaderleri paylaşmış, benzer ödevlerle yükümlü olmuş kişilerin topluluğu" (www.tdk.gov.tr) olarak tanımlanan kuşak kavramını doğru tanımlayabilmek için yalnızca doğum yıllarını kullanmak yerine, toplumsal değerler, tutumlar ve eğilimler üzerinde değişiklikler yaratan büyük olayların irdelendiği kohort kavramın, kohort etkisini ve değerinin iyice anlaşılması gerekmektedir (Erden Ayhün, 2013: 96). Çünkü kuşak teorisi belirli zaman aralığında doğan bireylerin yani aynı kuşağa ait kişilerin benzer değer yargılarına, davranışlara ve yaşam biçimlerine sahip olmalarını aynı çağda doğmuş olmalarına bağlamaktadır (Karadağ ve Dalgın, 2018: 26-27). Benzer şekilde Mannheim da (1928) belirli bir dönemde doğmuş olmayı kuşak tanımlaması için yeterli bulmamakta, bununla birlikte, hızlı bir toplumsal değişimi beraber yaşamayı, bunun neticesinde tutum ve davranışların benzer yönde etkilendiğini ifade etmektedir.

Kuşaklar, her ne kadar Sessiz kuşak gibi II. Dünya Savaşı öncesine dek gruplanmakta olsa da bu çalışmada II. Dünya Savaşı sonrasından itibaren Bebek Patlaması kuşağı ${ }^{*}$, X kuşağı, Y kuşağı ve Z kuşağı şeklinde bir sıra izlenerek ele alınmaktadır. Strauss ve Howe 'nin (1991) kuşaklara ilişkin sınıflandırmada kesin bir yol olmadığını yönündeki ifadesi de göz önünde bulundurulmalıdır. Buna göre, Sessiz kuşağın çocukları olarak bilinen BB kuşağı, II. Dünya Savaşı sonrasında, başka bir ifadeyle, 1946 ile 1964 yılları arasında doğan bireylerdir. Daha çok kitlesel tüketimin ve kitlesel pazarlamanın izlerini taşıyan bu kuşak, savaş sonrası birçok şeyin dönüşüme uğradığı bir zamanda dünyaya geldiklerinden zıtlıkları barındırarak bir yanlarıyla sadık, ilkeli, idealist, fedakâr, diğer yanlarıyla da bireyci, bohem, asi ve kural tanımaz, sanata, estetiğe ve özgürlüklere değer veren bir kuşak olarak görülmektedirler (Altıntuğ, 2012: 204). Daha çok kitlesel tüketimin ve kitlesel pazarlamanın etkisinde olduklarından televizyonu etkili bir iletişim aracı olarak kabul etmektedirler (Batı, 2015: 145). BB kuşağının bireylerinin yaşları nedeniyle birtakım fiziksel sinırlılıklar söz konusudur. Bu nedenle, BB turistleri uzun mesafeli seyahatlerden ziyade daha kısa mesafeli seyahatleri tercih edebilirler (Tiago vd., 2016: 20). Ancak tatil süresi bakımından, BB turistler diğer kuşaklara kıyasla daha uzun tatil sürelerini tercih etmektedirler (Karadağ ve

\footnotetext{
* Çalışmanın geri kalan kısmında Bebek Patlaması Kuşağı BB olarak kısaltılmıştır.
} 
Dalgın, 2018: 33). Bununla birlikte, bu kuşak mensubu turistler doğayı sevdiklerinden ve turizm tercihlerinden riskten kaçındıklarından Plog'un (1974) psikosentrik turist tipolojisini andırmaktadırlar (Özel, 2017: 10).

X kuşağı ise 1965-1979 yılları arasında doğan ve BB kuşağının çocukları olarak dünyaya gelen kişilerin üyesi olduğu kuşaktır. 70'li yıllarda yaşanan petrol krizinin ardından işletmelerin darboğaza girmesiyle ortaya çıkan çalkantı ve belirsizlik doğduklarından kimi kaynaklarda "kayıp kuşak" olarak da adlandırılan X kuşağı CD, uzaktan kumanda ve bilgisayar gibi teknolojiler ile belki de ilk tanışan kuşaktır (Özel, 2017: 10). Turizm tercihleri açısından değerlendirildiğinde, $\mathrm{X}$ kuşağının $\mathrm{Z}$ kuşağı gibi genç bireylere kıyasla daha uzun süreli tatilleri tercih ettikleri belirtilmektedir (Karadağ ve Dalgın, 2018). Peltomäki (2015) ise X kuşağının aileleri ile seyahate çıkma isteklerinin yüksek olduğunu, bu nedenle, seyahat süresince risklere karşı daha hassas olduklarını ifade etmektedir. Benzer şekilde, Li vd., (2013) X kuşağı turistlerinin daha fazla çocuklu seyahate çıktıklarını söylemektedir.

1980-1999 yılları arasında doğan bireyler Y kuşağını oluşturmaktadır. Kendinden önceki X kuşağı ile en öne çıkan farkları teknoloji ve tüketimle olan gönüllü ilişkileridir (Altıntuğ, 2012: 206). Bu nedenle, sosyal medya, web siteleri, arama motorları $\mathrm{Y}$ kuşağının dikkate aldığı referans kaynaklarıdır (Özel, 2017: 12). Roy vd.'ne (2015) göre, Y kuşağı kuşak araştırmalarından en çok odaklanılan gruptur çünkü hem tüketimle gönüllü ilişki içerisindedirler hem de yüksek satın alma potansiyeline sahiptirler. Önceki kuşaklara kıyasla popülasyon olarak kalabalık bir kuşak olan Y kuşağı için özgür seyahat edebilme imkânı, turizm fırsatlarının çoğalması, turistik destinasyonların ve faaliyetlerin çeşitlenmesi bu kuşağın turistlerinin yeni deneyimlere doğru geçişini hızlandırmaktadır (Güzel, 2018: 7). Özellikle son yıllarda popüler olan TripAdvisor ve Lonely Planet gibi internet sitelerini kullanarak Plog'un (1974) alosentrik turist tipolojisine yakın bir görünüm sergilemekle birlikte, bu kuşağa ilişkin tipolojilerin araştırılması önemli bir ihtiyacı ortaya koymaktadır (Özel, 2017: 14). Sosyalleşmeyi seven ve sosyal etkileşimi önemseyen bu kuşağın turistlerine (Güzel, 2018: 6), işletmeler her zaman sanal platformlar üzerinden erişilebilirlik ve sanal katılım imkânı sağlamalıdır (Stillmann, 2017: 55).

Z kuşağı, 2000 ve sonrası yılları doğan ve günümüzde en büyüğü 19 yaşında olan bireyleri kapsamaktadır. Bu kuşak literatürde 11 Eylül kuşağı, Her Daim Çevrimiçi kuşak, Özçekimler, Dijital Yerliler ve Yeni Sessiz kuşak olarak da yer almaktadır (Stillmann, 2017: 17). Her ne kadar bu kuşağın harcanabilir gelirleri şuan itibariyle düşük olsa da veya hiç olmasa da (Karadağ ve Dalgın, 2018: 29), Altıntuğ (2012) Z kuşağının pazarlama ve tüketim kalıplarını büyük ölçüde değiştireceklerini öngörmektedir. Bununla birlikte, marka sadakatlerinin az olduğu bilinen $Z$ kuşağı bireylerini sadık turistlere dönüştürmek üzere turizm işletmelerinin faaliyetlerini erken yaşlardan itibaren planlamaları, özellikle Z kuşağının ilerleyen yaşlarında da akılda kalacak bir marka imajı üzerine çalışmaları önemli olacaktır (Özel, 2017: 19).

\section{YÖNTEM}

Turizm tercihlerinde yönlendirici etkisi olduğu düşünülen uluslararası turist rollerinin kuşaklara göre farklılaşıp farklılaşmadığına dair bir incelemeyi hedefleyen bu çalışma alan araştırması yöntemi benimsenmiştir. Alan araştırmasında veri toplamada kullanılan anket iki kısımdan oluşmaktadır: İlk bölümde katılımcıların milliyeti, cinsiyeti, medeni durumu ve ait oldukları kuşak gibi demografik sorular yer almakta; ikinci kısımda ise Mo vd., (1993) tarafından geliştirilen "Uluslararası Turist Rolü" ölçeğinin ifadeleri bulunmaktadır. Söz konusu ölçek, dokuz ifadeden oluşan "destinasyon yönelimli boyutu", beş ifade ile ölçülen "seyahat hizmetleri boyutunu" ve altı ifadeden oluşan "sosyal temas boyutunu" içermektedir. Bu ifadelere, 
katılımcılardan 5'li Likert ölçeğine (1: Kesinlikle katılmıyorum......5: Kesinlikle katıllyorum) göre cevap vermeleri beklenmiştir. Bununla birlikte, araştırmada kullanılan ölçek hem Türk hem de yabancı turistlere uygulandığından dolayı geri-çeviri (back-translation) prosedürü izlenmiştir. $\mathrm{Bu}$ yöntemle, geçerliliği ve güvenilirliği test edilmiş orijinal ölçek, Türkçe ve İngilizce dillerine profesyonel düzeyde hakim olan ve turizm pazarlaması literatüründe de bilgisi olan iki akademisyen tarafından önce Türkçe'ye, daha sonra İngilizce'ye çevrilerek aradaki farklılıklar tespit edilmiştir. Daha sonra bu farklılıklar araştırmacılar tarafından düzenlenerek ve 50 katılımcı ile yürütülen pilot araştırmadan elde edilen geri dönüşler dikkate alınarak ankete son hali verilmiştir.

Araştırmanın evrenini 2018 yılında Muğla ili Bodrum ilçesini ziyaret eden yerli ve yabancı turistler oluşturmaktadır. Muğla ili ilçelerinden Bodrum'un seçilmesinin nedeni ise ilin diğer ilçelerine kıyasla Bodrum'un nüfus yoğunluğu açısından ilk sırada yer almasıdır (Sert, 2017). Buna göre, Bodrum ilçesine ulaşım için kullanılabilecek havalimanı ve deniz limanlarındaki giriş sayıları dikkate alındığında araştırmanın evren büyüklüğü 977.473 kişidir (www.muglakulturturizm.gov.tr). Saunders vd.'ne (2000) göre \%5 hata marji ile bu evren büyüklüğ̈̈nde ulaşılması gereken örneklem sayısı 384 olmalıdır. Bu hedef gözetilerek, araştırma verileri bölge turizminin yüksek olması nedeniyle 2018 yılının Nisan ve Kasım ayları arasında toplam 671 kişiden yüz yüze ve kolayda örnekleme yöntemiyle elde edilmiştir. Bu örneklem büyüklüğünün, Tavşancl'ın (2014) belirttiği gibi ölçekte yer alan ifade sayısının en az beş katı kişiye ulaşma kriterini fazlasıyla sağladığı görülmektedir. Bununla birlikte, çalışmadaki tüm test sonuçları \%95 güven düzeyine göre yorumlanmıştır.

\section{BULGULAR}

Araştırmada kullanılan ölçeğin güvenirliğine ilişkin yürütülen Cronbach Alfa testi bulgularına göre uluslararası turist rolü ölçeğinin güvenilirlik katsayısı $\alpha=0,713^{\prime}$ tür. Akgül ve Çevik'e (2005) göre araştırmada kullanılan ölçek oldukça güvenilirdir.

Kullanılan ölçeğin geçerliliğini test etmek için faktör analizinden faydalanılmıştır. Faktör analizi öncesi veri setine ön testler uygulanmış ve verilerin faktör analizine elverişli olduğuna karar verilmiştir. Tablo 1, faktör analizi sonuçlarını göstermektedir.

Tablo 1. Faktör Analizi Bulguları

\begin{tabular}{|c|c|c|c|c|}
\hline & \begin{tabular}{|c|} 
Destinasyon \\
Yönelimi \\
Açklanan Varyans \\
$(\%): 30,345$
\end{tabular} & $\begin{array}{c}\text { Sosyal } \\
\text { Temas } \\
\text { Yönelimi } \\
\\
\text { Açklanan } \\
\text { Varyans (\%): } \\
27,841\end{array}$ & $\begin{array}{c}\text { Seyahat } \\
\text { Hizmetleri } \\
\text { Yönelimi } \\
\\
\text { Açklanan } \\
\text { Varyans (\%): } \\
\text { 19,486 }\end{array}$ & $\begin{array}{c}\text { Kültür } \\
\text { Yönelimi } \\
\\
\text { Açıklanan } \\
\text { Varyans (\%): } \\
9,420\end{array}$ \\
\hline $\begin{array}{l}\text { Popüler olan destinasyonlara (bölgelere) } \\
\text { seyahat etmeyi tercih ederim. } \\
\text { Restoranların bana aşina olduğu ülkelere } \\
\text { seyahat etmeyi tercih ederim. } \\
\text { Destinasyonları (bölgeleri) düşünürken aşina } \\
\text { olma konusuna öncelik veririm. } \\
\text { Turizm sektörünün oldukça gelişmiş olduğu } \\
\text { ülkelere seyahat etmeyi tercih ederim. }\end{array}$ & $\begin{array}{l}, 932 \\
, 927 \\
, 921 \\
, 906\end{array}$ & & & \\
\hline
\end{tabular}




\begin{tabular}{|c|c|c|c|c|}
\hline $\begin{array}{l}\text { Ülkemdeki ulaştırma sistemiyle aynı olan } \\
\text { ülkelere seyahat etmeyi tercih ederim. } \\
\text { Ülkemdeki turizm altyapısıla (otoban, su } \\
\text { tedarik, kanalizasyon, elektrik gücü ve iletişim } \\
\text { ağı gibi) aynı ülkelere seyahat etmeyi tercih } \\
\text { ederim. } \\
\text { Yabancı bir ülkeye seyahat ederken } \\
\text { uluslararası zincir otellerde kalmayı tercih } \\
\text { ederim. }\end{array}$ &, 847 & & & \\
\hline $\begin{array}{l}\text { Yabancı bir ülkeye seyahat ederken yerel } \\
\text { halkla arkadaşlık etmeyi tercih ederim. } \\
\text { Birçok yeni ve farklı insanla doğrudan temas } \\
\text { kurarak yeni heyecan arayışında olmayı tercih } \\
\text { ederim. } \\
\text { Yabancı bir ülkeye seyahat ederken yerel } \\
\text { halkla mümkün olduğunca çok iletişimde } \\
\text { olmayı tercih ederim. } \\
\text { Tatillim süresince yerel halkın evini, yemeğini, } \\
\text { örf ve adetlerini paylaşarak yaşamayı tercih } \\
\text { ederim. } \\
\text { Yabancı bir ülkeye seyahat ederken yerel } \\
\text { halkla ilişki kurmayı tercih ederim. } \\
\text { Beni memnun eden bir yer bulduğumda, orada } \\
\text { uzun bir süre durup sosyal hayatla } \\
\text { kaynaşabileceğim bir yer oluştururum. }\end{array}$ & & $\begin{array}{l}, 919 \\
, 919 \\
, 811 \\
, 899 \\
, 876\end{array}$ & & \\
\hline $\begin{array}{l}\text { Yabancı bir ülkeye seyahat ederken seyahat } \\
\text { acentesinin benimle başından sonuna kadar } \\
\text { ilgilenmesini tercih ederim. } \\
\text { Yabancı bir ülkeye seyahat ederken rehberli tur } \\
\text { hizmetlerinden yararlanmayı tercih ederim. } \\
\text { Yurtdışna seyahat ederken seyahat } \\
\text { acenteleriyle büyük anlaşmalar yapmayı tercih } \\
\text { ederim. } \\
\text { Yabancı bir ülkeye seyahat ederken önceden } \\
\text { plan yaparak veya belirli bir rota oluşturarak } \\
\text { yolculuğa başlamayı tercih ederim. } \\
\text { Yabancı bir ülkeye seyahat ederken önceden } \\
\text { plan yapmadan veya belirli bir rota } \\
\text { oluşturmadan yolculuğa başlamayı tercih } \\
\text { ederim. (ters kodlama) }\end{array}$ & & & $\begin{array}{l}, 866 \\
, 831 \\
, 804 \\
, 799 \\
, 754\end{array}$ & \\
\hline $\begin{array}{l}\text { Kendi kültürüm ile benzer kültürdeki ülkelere } \\
\text { seyahat etmeyi tercih ederim. } \\
\text { İnsanların benim etnik grubum ile aynı olduğu } \\
\text { ülkelere seyahat etmeyi tercih ederim. }\end{array}$ & & & & ,965 \\
\hline
\end{tabular}

Kaiser-Meyer-Olkin Örneklem Ölçümü =0,901; Bartlett's Test of Sphericity =20623,722; Toplam farkın (Varyans) açıklama oranı: \%87,092 
Tablo 1'de sunulan faktör analizi bulgularına göre, uluslararası turist rolü ölçeği ifadeleri dört boyut altında toplanmaktadır. Orijinal ölçekten farklı olarak, destinasyon tercihinde bulunurken ilgili kültür ve etnik gruba ilişkin ifadelerin ayrı bir boyut oluşturdukları görülmektedir. Bu nedenle, söz konusu boyut bu çalışmada "kültür yönelimi" olarak isimlendirilmiştir. Diğer boyutlar, orijinal ölçek ile birebir uyum göstermiş olup, "destinasyon yönelimi", "sosyal temas yönelimi" ve "seyahat hizmetleri yönelimi" olarak nitelendirilmiştir. Bununla birlikte, araştırmaya katılanların demografik bulguları ise Tablo 2' de yer almaktadır.

Tablo 2. Demografik Bulgular

\begin{tabular}{|c|c|c|c|c|c|}
\hline Değişken & Frekans & $\%$ & Değişken & Frekans & $\%$ \\
\hline $\begin{array}{c}\text { Cinsiyet } \\
\text { Kadın } \\
\text { Erkek } \\
\text { Toplam }\end{array}$ & $\begin{array}{l}350 \\
321 \\
671\end{array}$ & $\begin{array}{r}52,2 \\
47,8 \\
100,0\end{array}$ & $\begin{array}{c}\text { Medeni Durum } \\
\text { Evli } \\
\text { Bekar } \\
\text { Kayıp Veri } \\
\text { Toplam }\end{array}$ & $\begin{array}{r}513 \\
155 \\
3 \\
671\end{array}$ & $\begin{array}{r}76,5 \\
23,1 \\
0,4 \\
100,0\end{array}$ \\
\hline $\begin{array}{l}\text { Kuşak } \\
\text { BB Kuşağ1 } \\
\text { X Kuşağ1 } \\
\text { Y Kuşağ1 } \\
\text { Z Kuşağ1 } \\
\text { Toplam }\end{array}$ & $\begin{array}{r}84 \\
230 \\
220 \\
137 \\
671\end{array}$ & $\begin{array}{r}12,5 \\
34,3 \\
32,8 \\
20,4 \\
100,0\end{array}$ & $\begin{array}{ll}\text { Uyruk } \\
& \text { Türk } \\
& \text { Polonyalı } \\
\text { İngiliz } & \text { Belçikalı } \\
\text { Hollandalı } \\
\text { Alman } \\
\text { Rus } \\
\text { Ukraynalı } \\
\text { Diğer } \\
\text { Toplam }\end{array}$ & $\begin{array}{r}183 \\
90 \\
79 \\
61 \\
43 \\
42 \\
34 \\
15 \\
124 \\
671\end{array}$ & $\begin{array}{r}27,3 \\
13,4 \\
11,8 \\
9,1 \\
6,4 \\
6,3 \\
5,1 \\
2,2 \\
18,5 \\
100,0\end{array}$ \\
\hline
\end{tabular}

Demografik bulgulara göre, katılımciların \%52,2'si kadın ve \%47,8'i erkektir. Bununla birlikte, $\% 76,5$ oranında katılımcının evli olduğu görülmektedir. Kuşak dağılımlarına bakıldığında, $X$ kuşağı $(\% 34,3)$ ve Y kuşağı $(\% 32,8)$ katılımcılarının ağırlıkta olduğu dikkati çekmektedir. Uyruklara ilişkin ise Türk katılımcıların büyük çoğunluğu oluşturduğu $(\% 27,3)$, Türkleri "diğer" başlığındaki katılımcılar izlemekte $(\% 18,5)$, ardından sırasıyla Polonyalı (\%13,4), İngiliz $(\% 11,8)$, Belçikalı $(\% 9,1)$, Hollandalı $(\% 6,4)$, Alman $(\% 6,3)$, Rus $(\% 5,1)$ ve Ukraynalı katılımclar $(\% 2,2)$ yer almaktadır.

Demografik bulguların ardından, uluslararası turist rolü boyutları açısından kuşak grupları arasında fark olup olmadığını test etmek üzere ANOVA uygulanmış olup, buna ilişkin oluşturulan hipotezler ve ANOVA bulguları ilerleyen tablolarda yer almaktadır.

Tablo 3. Destinasyon Yönelimine İlişkin ANOVA Bulguları

\begin{tabular}{|l|r|r|r|r|r|}
\hline & \multicolumn{1}{|c|}{ KT } & \multicolumn{1}{|c|}{ Sd } & KO & \multicolumn{1}{c|}{ F } & \multicolumn{1}{c|}{ p } \\
\hline Gruplar Arası & 74,164 & 3 & 24,721 & 24,479 &, 000 \\
Grup İçi & 672,595 & 666 & 1,010 & & \\
Toplam & 746,759 & 669 & & & \\
\hline
\end{tabular}

$\boldsymbol{H}_{1}$ : Destinasyon yönelimi açısından cinsiyet grupları arasında farklılık vardır.

Tablo 3'teki bulgulara göre, destinasyon yönelimi boyutu açısından kuşaklar arasında anlamlı bir farklılık söz konusu olduğu için $\boldsymbol{H}_{1}$ reddedilememektedir. Farklılığın hangi kuşaktan kaynaklandığını değerlendirmek üzere yapılan çoklu karşılaştırma testi sonuçları ise Tablo 4 'te yer almaktadır. 
Tablo 4. Destinasyon Yönelimine İlişkin Çoklu Karşılaştırma Testi Bulguları (Tamhane)

\begin{tabular}{|c|c|c|c|c|}
\hline (I) & $(\mathrm{J})$ & Ort. Fark (I-J) & Std. Hata & p \\
\hline \multirow[t]{3}{*}{ BB } & $X$ & 25395 & 11635, & 170 \\
\hline & Y & ,41212* & 11686 & ,003 \\
\hline & Z & $1,04283^{*}$ & 14838, & ,000 \\
\hline \multirow[t]{3}{*}{$X$} & BB &,- 25395 & ,11635 & , 170 \\
\hline & Y & 15818, & 08670, & ,348 \\
\hline & Z & ,78888* & 12600 & ,000 \\
\hline \multirow[t]{3}{*}{$\bar{Y}$} & BB &,$- 41212^{*}$ & 11686, & ,003 \\
\hline & $X$ & 15818,- & 08670, & ,348 \\
\hline & Z & ,63070* & 12647, & , 000 \\
\hline \multirow[t]{3}{*}{$\bar{Z}$} & $\mathrm{BB}$ & $-1,04283^{*}$ & , 14838 & ,000 \\
\hline & $x$ &,$- 78888^{*}$ & 12600 & ,000 \\
\hline & $\mathrm{Y}$ &,$- 63070^{*}$ & 12647, & ,000 \\
\hline
\end{tabular}

Tablo 4'teki farklar dikkate alındığında, BB kuşağının Y kuşağına göre, yine BB kuşağının Z kuşağına göre, $X$ kuşağının $Z$ kuşağına göre, $Y$ kuşağının $Z$ kuşağına göre daha fazla destinasyon yönelimli olduğu söylenebilmektedir. Başka bir ifadeyle, kuşaklar gençleştikçe destinasyon yönelimi eğilimi azalmaktadır.

Tablo 5. Sosyal Temas Yönelimine İlişkin ANOVA Bulguları

\begin{tabular}{|l|r|r|r|r|r|}
\hline & \multicolumn{1}{|c|}{ KT } & \multicolumn{1}{|c|}{ Sd } & \multicolumn{1}{c|}{ KO } & \multicolumn{1}{c|}{$\mathrm{F}$} & \multicolumn{1}{c|}{$\mathrm{p}$} \\
\hline Gruplar Arasi & 146,921 & 3 & 48,974 & 36,547 &, 000 \\
Grup İici & 893,800 & 667 & 1,340 & & \\
Toplam & 1040,721 & 670 & & & \\
\hline
\end{tabular}

$\boldsymbol{H}_{2}$ : Sosyal temas yönelimi açısından kuşaklar arasında farklılık vardır.

Sosyal temas yönelimi boyutuna ilişkin ANOVA bulgularındaki anlamlılık düzeyine göre $\boldsymbol{H}_{2}$ reddedilemez. Farklılığın kaynaklandığı kuşağı belirlemek için yürütülen çoklu karşılaştırma testi sonuçları Tablo 6 'da görülmektedir.

Tablo 6. Sosyal Temas Yönelimine İlişkin Çoklu Karşılaştırma Testi Bulguları (Tamhane)

\begin{tabular}{|c|c|c|c|c|}
\hline (I) & (J) & Ort. Fark (I-J) & Std. Hata & $\mathrm{p}$ \\
\hline \multirow[t]{3}{*}{ BB } & $X$ &,$- 67013^{*}$ & ,12521 & , 000 \\
\hline & $Y$ &,$- 73874^{*}$ & 12693 & ,000 \\
\hline & Z & $-1,60354^{*}$ & 14039 & ,000 \\
\hline \multirow[t]{3}{*}{$x$} & BB & ,67013* & ,12521 & ,000 \\
\hline & Y &,- 06861 & 11257 & 991 \\
\hline & Z &,$- 93340^{*}$ & 12755 & ,000 \\
\hline \multirow[t]{3}{*}{$Y$} & $\overline{B B}$ & ,73874* & 12693 & ,000 \\
\hline & $x$ & 06861 & 11257 & 991 \\
\hline & Z &,$- 86479^{*}$ & 12925 & ,000 \\
\hline \multirow[t]{3}{*}{$Z$} & BB & $1,60354^{*}$ & 14039 & ,000 \\
\hline & $x$ &, $93340^{*}$ & 12755 & ,000 \\
\hline & Y &, $86479^{*}$ & 12925 & ,000 \\
\hline
\end{tabular}


Tablo 6'ya göre, $Z$ kuşağı $B B, X$ ve $Y$ kuşaklarına kıyasla daha fazla sosyal temas yönelimlidir. Bununla birlikte, $X$ kuşağ $\mathrm{BB}^{\prime}$ ye göre, $\mathrm{Y}$ kuşağ $\mathrm{da} \mathrm{BB}^{\prime}$ ye göre turizm tercihlerinde sosyal temasa daha fazla önem vermektedir. Turizm tercihinde bulunacak kişilerin ait oldukları kuşak günümüze doğru yaklaştığında sosyal temas yönelimi artmaktadır, başka bir ifadeyle, sosyal temas turizm kararlarında daha ağır basmaktadır.

Tablo 7. Seyahat Hizmetleri Yönelimine İlişkin ANOVA Bulguları

\begin{tabular}{|l|r|r|r|r|r|}
\hline & \multicolumn{1}{|c|}{ KT } & \multicolumn{1}{|c|}{ Sd } & KO & \multicolumn{1}{c|}{ F } & \multicolumn{1}{c|}{ p } \\
\hline Gruplar Arasi & 158,560 & 3 & 52,853 & 36,990 &, 000 \\
Grup İçi & 953,035 & 667 & 1,429 & & \\
Toplam & 1111,595 & 670 & & & \\
\hline
\end{tabular}

$\boldsymbol{H}_{3}$ : Seyahat hizmetleri yönelimi açısından kuşaklar arasında farklılık vardır.

Oluşturulan $\boldsymbol{H}_{3}$ hipotezini test etmek için yürütülen ANOVA bulgularına göre, seyahat hizmetleri yönelimi açısından kuşak grupları arasında anlamlı fark vardır ve söz konusu hipotez kabul edilir. Tablo 8, kuşakların seyahat yönelimi açısından aldıkları farklılıklara ilişkin ileri test bulgularını sunmaktadır.

Tablo 8. Seyahat Hizmetleri Yönelimine İlişkin Çoklu Karşılaştırma Testi Bulguları (Tamhane)

\begin{tabular}{|c|c|c|c|c|}
\hline (I) & (J) & Ort. Fark (I-J) & Std. Hata & $p$ \\
\hline \multirow[t]{3}{*}{$\mathrm{BB}$} & $x$ & , $85652^{*}$ & ,11917 & , 000 \\
\hline & $\mathrm{Y}$ & ,98000* & ,12734 & ,000 \\
\hline & Z & $1,71752^{*}$ & ,13781 & , 000 \\
\hline \multirow[t]{3}{*}{$X$} & $\overline{\mathrm{BB}}$ &,$- 85652^{*}$ & ,11917 & , 000 \\
\hline & $\mathrm{Y}$ & 12348 & ,11783 & 877 \\
\hline & Z & ,86100* & ,12907 & ,000 \\
\hline \multirow[t]{3}{*}{$\mathrm{Y}$} & BB &,$- 98000^{*}$ & ,12734 & ,000 \\
\hline & $x$ &,- 12348 & ,11783 & 877 \\
\hline & Z & ,73752* & ,13665 & ,000 \\
\hline \multirow[t]{3}{*}{$\mathrm{Z}$} & $\mathrm{BB}$ & $-1,71752^{*}$ & 13781 & ,000 \\
\hline & $x$ &,$- 86100^{*}$ & ,12907 & ,000 \\
\hline & $\mathrm{Y}$ &,$- 73752^{*}$ & ,13665 & ,000 \\
\hline
\end{tabular}

Farklılık testi bulguları, BB kuşağının $X, Y$ ve $Z$ kuşaklarından, $X$ kuşağının $Z$ kuşağından, $Y$ kuşağının ise $Z$ kuşağına göre daha fazla seyahat hizmetleri yönelimli olduğuna işaret etmektedir. Buna göre, kuşaklar BB kuşağından $Z$ kuşağına doğru ilerledikçe turizm tercihlerinde seyahat hizmetleri yöneliminin etkisi azalmaktadır.

Tablo 9. Kültür Yönelimine İlişkin ANOVA Bulguları

\begin{tabular}{|l|r|r|r|r|r|}
\hline & \multicolumn{1}{|c|}{ KT } & \multicolumn{1}{c|}{ Sd } & \multicolumn{1}{c|}{ KO } & \multicolumn{1}{c|}{ F } & \multicolumn{1}{c|}{ p } \\
\hline Gruplar Aras1 & 7,774 & 3 & 2,591 & 3,048 &, 028 \\
Grup İçi & 567,155 & 667 &, 850 & & \\
Toplam & 574,928 & 670 & & & \\
\hline
\end{tabular}

H: Kültür yönelimi açısından kuşaklar arasında farklılık vardır. 
Tablo 10' da kültür yönelimi açısından kuşak gruplarındaki farklılığa ilişkin yürütülen ANOVA bulguları yer almaktadır. Buna göre, $\boldsymbol{H}_{4}$ hipotezi reddedilememektedir. Çoklu karşılaştırma testi bulguları ise Tablo $10^{\prime}$ da sunulmaktadır.

Tablo 10. Kültür Yönelimine İlişkin Çoklu Karşılaştırma Testi Bulguları (Tukey)

\begin{tabular}{|ll|r|r|r|}
\hline & & & \\
$(\mathrm{I})$ & $\mathrm{J})$ & Ort. Fark (I-J) & Std. Hata & $\mathrm{p}$ \\
\hline BB & $\mathrm{X}$ &,- 15590 &, 11756 &, 547 \\
& $\mathrm{Y}$ &,- 07468 &, 11827 &, 922 \\
& $\mathrm{Z}$ &, 13816 &, 12779 &, 701 \\
\hline $\mathrm{X}$ & BB &, 15590 &, 11756 &, 547 \\
& $\mathrm{Y}$ &, 08123 &, 08696 &, 787 \\
& $\mathrm{Z}$ &, $29407^{*}$ &, 09952 &, 017 \\
\hline $\mathrm{Y}$ & BB &, 07468 &, 11827 &, 922 \\
& $\mathrm{X}$ &,- 08123 &, 08696 &, 787 \\
& $\mathrm{Z}$ &, 21284 &, 10036 &, 148 \\
\hline $\mathrm{Z}$ & BB &,- 13816 &, 12779 &, 701 \\
& $\mathrm{X}$ &,$- 29407^{*}$ &, 09952 &, 017 \\
& Y &,- 21284 &, 10036 &, 148 \\
\hline
\end{tabular}

Tablo 10'daki farklılık testi bulgularına göre, yalnızca X kuşağı ile Z kuşağı arasında anlamlı fark söz konusudur. Başka bir ifadeyle, $X$ kuşağı $Z$ kuşağına kıyasla daha fazla kültür yönelimli tercihlerde bulunmaktadır.

\section{SONUÇ ve ÖNERILER}

Pazar bölümlendirme geleneksel pazarlamada olduğu gibi turizm pazarlamasının da stratejik karar alanlarından biridir. Pazar bölümlendirme ile her turizm işletmesi gerek kaynaklarını gerekse çabalarını daha etkin şekilde yürütebilecektir. Bölümlendirme kriterleri ise çeşitli koşullara göre farklılık gösterebilmekte; bazen demografik bazen de psikografik temellere dayanan pazar grupları ortaya konmaktadır.

Son yıllarda birçok disiplinde inceleme konusu olan kuşak kavramı turizm alanında da sıklıkla araştırılmaya başlanan bir konudur. Bu bağlamda, kuşakların dönüşüm süreçlerinin anlaşılması diğer sektörlerde olduğu gibi turizm sektöründe de önemli olmakla birlikte (Güzel, 2018), pazarı anlamlı biçimde bölümlendirmek için gereklidir. Dahası, pazarın bölümlendirilmesinde kuşakların farklı değer yargılarının ve davranışlarının incelenmesine ek olarak, turizm literatüründe sıklıkla araştırılan tipolojiler konusu da eklemek elde edilen içgörüleri zenginleştirecek ve daha doğru pazarlama kararlarına ulaşmayı mümkün kılacaktır.

Bu doğrultuda, Muğla ili Bodrum ilçesini 2018 yılında ziyaret eden yerli ve yabancı turistlerin kuşak grupları ile Mo vd., (1993) tarafından geliştirilen uluslararası turist rolü tipolojisi ilişkisini test etmeyi amaçlayan bu çalışma, literatürde daha önce yeterince sinanmayan kuşak-tipoloji ilişkisine dair önemli bulgular sunmaktadır. Öncelikle, uluslararası turist rolü tipolojisinde ayrışan "kültür yönelimi" boyutu çalışmanın turizm literatürüne sağladığı önde gelen katkılarındandır. Uluslararası turist rolü tipolojisinin destinasyon yönelimi, sosyal temas yönelimi, seyahat hizmetleri yönelimi ve kültür yönelimi boyutlarında kuşaklar arası 
farklılıkların istatistiki olarak anlamlı olması dikkate değerdir. Buna göre, destinasyon yönelimi kuşaklar gençleştikçe azalmaktadır. Farklı bir ifadeyle, destinasyona bağlı turizm kararları daha çok yaşlı turistler olarak nitelendirilebilecek BB kuşağının bireylerinde görülmektedir. Bu bulgu, nispeten daha yaşlı turistlerin kitlesel turizmde daha fazla yer almalarıyla örtüşmektedir. Li vd.'nin (2013) belirttiği gibi BB kuşağı turistleri daha çok kültür turları, ören yerleri ve tarihi yerleri ziyaret gibi daha çok kitlesel seyahat aktivitelerini tercih etmektedir. Gardiner vd. (2014) kuşaklar üzerine yürüttüğü çalışmalarında $B B$ kuşağı ve $X$ kuşağı gibi $Y$ ve $Z$ kuşaklarına göre daha yaşlı turistler için kitlesel medya araçlarının önemine işaret etmektedir. Benzer şekilde, seyahat hizmetleri yöneliminde de BB kuşağından Z kuşağına doğru ilerledikçe turizm kararlarında seyahat hizmetleri daha az dikkate alınmaktadır. Carlsen ve Getz'in (2006) şarap turizmi deneyimine ilişkin çalışmalarında $X$ kuşağının $Y$ kuşağ 1 turistlerine kıyasla tur ile ilgili bilgi edinme ya da turun uzunluğu gibi konularda konfor bekledikleri yönündeki bulgu seyahat hizmetlerini daha yaşlı kuşakların önemsediğini göstermektedir. Kültür yöneliminde ise yalnızca $X$ kuşağı ve Z kuşağı turistlerinin farklılaştığı söylenebilir. Başka bir ifadeyle, $X$ kuşağı Z kuşağı turistlerine kıyasla daha fazla kültür yönelimli bir tipolojiye sahiptirler. Literatürde de $X$ kuşağının turizme olan merakının yeni kültürleri ve farklı etnik grupları tanımaktan kaynaklandığı ifade edilmektedir (Özel, 2017: 11). Araştırmanın en dikkat çekici bulgularından biri sosyal temas yönelimi tipolojisinde ortaya çıkmıştır. Kendinden önceki kuşaklara kıyasla sosyal teması en fazla referans alan ve kararlarında buna öncelik veren kuşak Z kuşağıdır. Dahası, turistler Z kuşağından BB kuşağına doğru yaş aldıkça sosyal temas yönelimli olmaktan uzaklaşmaktadır. Bu bulgudan farklı olarak Özel (2017) sanıldığının aksine Y kuşağının sosyalleşmeyi ve diğer insanlarla birlikte vakit geçirmeyi tatillerinde çok tercih etmediğini belirtmektedir.

Bu bulgulara dayanarak turizm pazarlamacılarının ve sektördeki karar vericilerin kuşaklar arası farklılıkları dikkate almaları önemli görülmektedir. Çünkü her kuşağın kendine özgü değerleri, öncelikleri veya tutumları uluslararası turist rolü tipolojisi ile incelendiğinde ciddi derecede ayrışmalar ortaya çıkmaktadır. Buna göre, BB kuşağı ya da $X$ kuşağı gibi yaşları daha ileri olan turistlerin hedef pazar olarak seçildiği durumlarda destinasyon yönelimi ve seyahat hizmetleri yönelimi üzerine daha detaylı düşünmek ve stratejileri bu boyutlarda kurgulamak gerekmektedir. Eğer $\mathrm{Y}$ kuşağı veya $\mathrm{Z}$ kuşağ turistlerini çekmek söz konusu ise, destinasyon yönelimi ve seyahat hizmetleri yöneliminin etkisi azalarak sosyal temas yönelimi öne çıkmaktadır. Günümüzde internet teknolojisi sayesinde çeşitli uygulamalar vasitasıyla henüz destinasyonu ziyaret etmeden öncesinde bile yerel halk ile temas kurmak mümkündür.

Son olarak, çalışmanın turizm literatüründe yaygın olarak incelenen Cohen ya da Plog'un tipolojileri yerine Mo vd. (1993) tarafından öne sürülen uluslararası turist rolü tipolojisiyle sınırlı kalması bir kısıt olarak görülebilir. Bu nedenle, diğer turist tipolojileri ile kuşakların ilişkisi farklı yöntemlerle araştırılmaya değerdir. Bunun dışında, Z kuşağına ilişkin araştırma bulguları oldukça azdır çünkü kuşağın bireylerinin en büyügü henüz 19 yaşında olup, tatil kararlarını çoğunlukla kendi başlarına almamaktadırlar. Dolayısıyla, kuşaklara yönelik araştırmaların daha çok Z kuşağı turistlerini kapsaması literatürü zenginleştirecek bir öneridir.

\section{KAYNAKÇA}

Akgül, A. ve Çevik, O. (2005). İstatistiksel Analiz Teknikleri “SPSS'te İşletme Yönetimi Uygulamaları. Ankara: Emek Ofset.

Altıntuğ, N. (2012). Kuşaktan Kuşağa Tüketim Olgusu ve Geleceğin Tüketici Profili. Organizasyon ve Yönetim Bilimleri Dergisi, 4(1): 203-212. 
Batı, U. (2015). Tüketici Davranışları Tüketim Kültürü, Psikoloji ve Sosyolojisi Üzerine Şeytanın Notları. İstanbul: Beta Yayıncılık.

Carlsen, J. and Getz, D. (2006). What Do Generations X and Y Want in a Wine Tourism Experience? An Application of Importance-performance Evaluation to a Youthtargeted Wine Tour. 3rd International Wine Business Research Conference Proceedings (ss. 1-22). Montpellier.

Chen, G. and Huang, S. S. (2018a). Towards an Improved Typology Approach to Segmenting Cultural Tourists, International Journal of Tourism Research, 20: 247-255.

Chen, G. and Huang, S. S. (2018b). Understanding Chinese Cultural Tourists: Typology and Profile, Journal of Travel \& Tourism Marketing, 35(2): 162-177.

Coccossis, H. and Constantoglou, M. (2006). The Use of Typologies in Tourism Planning: Problems and Conflicts, 46th Congress of the European Regional Science Association (ERSA).

Cohen, E., (1972). Towards a Sociology of International Tourism, Social Research, 39(1): 164-182.

Erden Ayhün, S. (2013). Kuşaklar Arasındaki Farklılıklar ve Örgütsel Yansımaları, Ekonomi ve Yönetim Araştırmaları Dergisi, 2(1): 93-112.

Fan, D. X. F., Zhang, H. Q., Jenkins, C. L. and Tavitiyaman, P. (2017). Tourist Typology in Social Contact: An Addition to Existing Theories, Tourism Management, 60: 357-366.

Gardiner, S., Grace, D. and King, C. (2014). The Generation Effect: The Future of Domestic Tourism in Australia. Journal of Travel Research, 53(6): 705-720.

Güzel, Ö. (2018). Kuşakların Değişen Ruhu: Milenyum Kuşağı Turistlerini Anlamak ve Çözümlemek, (Editör) Özkoç, H. H. ve Bayrakdaroğlu, F.: Kuşak Kavramına Disiplinler Arası Bakış 2 içinde (ss. 1-21), Ankara: Nobel Yayıncllık.

http://sozluk.gov.tr/ (Erişim Tarihi: 14.04.2019)

http://www.muglakulturturizm.gov.tr/Eklenti/61351,aralikpdf.pdf?0 (Erişim Tarihi: 23.05.2019)

Jiang, J., Havitz, M. E. and O'Brien, R. M. (2000). Validating the International Tourist Role Scale. Annals of Tourism Research, 27(4): 964-981.

Karadağ, L. ve Dalgın, T. (2018). Tatil Tercihlerinde ve Satın Alma Sürecinde Kuşaklararası Yolculuk, (Editör) Özkoç, H. H. ve Bayrakdaroğlu, F.: Kuşak Kavramına Disiplinler Arası Bakış 2 içinde (ss. 23-36), Ankara: Nobel Yayıncilık.

Kayar, Ç. H. (2008). Tatil Kararı Verme Tarzına Dayalı Bir Tipoloji (çeviri makale). Anatolia: Turizm Araştırmaları Dergisi, 19(1): 84-92.

Li, X., Li, X. R., and Hudson, S. (2013). The Application of Generational Theory to Tourism Consumer Behavior: An American Perspective. Tourism Management, 37: 147-164.

Lin, Z., You, K., Lau, C. K. and Demir, E. (2019). Segmenting Global Tourism Markets: A Panel Club Convergence Approach, Annals of Tourism Research, 75(C): 165-185.

Mannheim, K. (1928). The Problem of Generations, (Editör) Kecskemeti, P.: Karl Mannheim Essays içinde, New York: Routledge Press.

Mo, C-m., Howard, D. R. and Havitz, M. E. (1993). Testing an International Tourist Role Typology, Annals of Tourism Research, 20(2): 319-335.

Morrison, A. M. (2010). Hospitality and Travel Marketing. Delmar Cengage Learning. 
Özel, Ç. H. (2017). Kuşak Kavramı ve Turizme Yansımaları, (Editör) Özkoç, H. H. ve Bayrakdaroğlu, F.: Kuşak Kavramına Disiplinler Arası Bakış içinde (ss. 1-25), Ankara: Nobel Yayıncilik.

Peltomäki, S. M. (2015). Crises in the Tourism Industry and Their Effects on Different Generations, Yayımlanmamış Yüksek Lisans Tezi, HAAGA-HELIA University of Applied Sciences.

Plog, S. C. (1974). Why Destination Areas Rise and Fall in Popularity, The Cornell Hotel and Restaurant Administration Quarterly, 14(2): 55-58.

Plog, S. C. (1977). Why Destination Areas Rise and Fall in Popularity, (Editör) Kelly, E.:Domestic and International Tourism içinde, Wellesey, MA: Institute of Certified Travel Agents.

Roy, S., Guha, A. and Biswas, A. (2015). Celebrity Endorsements and Women Consumers in India: How Generation-cohort Affiliation and Celebrity-product Congruency Moderate the Benefits of Chronological Age Congruency. Marketing Letters, 26(3): 363-376.

Saunders, M., Lewis, P. and Thornhill, A. (2000). Research Methods for Business Students. Financial Times/ Prentice Hall.

Sert, M. (2017). Muğla İş ve Yatırım Ortamı. GEKA Muğla Yatırım Destek Ofisi.

Stillman, D. ve Stilmann J. (2017). İşte Z Kuşă̆ı Genç Kuşak İşyerini Nasıl Dönüştürüyor. (Çeviren Kayıhan, D. A. ve Erduran, F.) İstanbul: İKÜ Yayınevi.

Strauss, W. and Howe, N. (1991). Generations: The History of America's Future, 1584 to 2069. New York: William Morrow and Company.

Tavşancıl, E. (2014). Tutumların Ölçülmesi ve SPSS ile Veri Analizi. (5. Basım), Ankara: Nobel Yayın Dağıtım.

Tiago, M. T. P. M. B., Couto, J. P. de A., Tiago, F. G. B. and Faria, S. M. C. D. (2016). Baby Boomers Turning Grey: European Profiles. Tourism Management, 54: 13-22. 